University of Wollongong

Research Online

Faculty of Law, Humanities and the Arts Papers (Archive)

Faculty of Arts, Social Sciences \& Humanities

$1-1-2015$

Stemming the black tide: cooperation on oil pollution preparedness and response in the South China Sea and East Asian Seas

Robin M. Warner

University of Wollongong, rwarner@uow.edu.au

Follow this and additional works at: https://ro.uow.edu.au/lhapapers

Part of the Arts and Humanities Commons, and the Law Commons

Research Online is the open access institutional repository for the University of Wollongong. For further information contact the UOW Library: research-pubs@uow.edu.au 


\title{
Stemming the black tide: cooperation on oil pollution preparedness and response in the South China Sea and East Asian Seas
}

\begin{abstract}
As global hydrocarbon resources on shore steadily decline, there has been an increase in offshore hydrocarbon exploration and exploitation. Some estimates suggest that there are over 6,000 offshore oil and gas installations worldwide. Notwithstanding simmering disputes over the territorial sovereignty and associated maritime zones of a number of island groups in the South China Sea and adjacent East Asian seas, exploration for offshore oil and gas resources under national and joint development regimes has become a prominent feature of these areas. It is estimated that there are now over 1,390 offshore oil and gas installations in the South China Sea and East Asian seas. This raises the question of how well prepared states bordering the South China Sea and the broader East Asian seas are to respond to a major oil spill from an offshore installation in the region. In recent years, two spectacular oil spills from offshore installations have occurred, one off the northwest shelf of western Australia from the Montara platform in 2009, and the other in the Gulf of Mexico from the Deepwater Horizon rig in 2010. Leaking oil from those incidents over a number of months caused major damage to the coastlines of the states with jurisdiction over the drilling as well as those of neighbouring states. The damage to the marine resources and biodiversity of the surrounding waters was extensive, and industries dependent on the environmental integrity and health of these waters suffered commensurately. In addition, the costs of cleaning up such widespread and injurious oil spills were huge.

Almost a third of global crude oil and half of global liquefied natural gas (LNG) passes through the South China Sea annually. China is also the world's largest oil importer. All these factors contribute to the high potential for an oil or gas spill disaster in the South China Sea and the broader East Asian seas. This article will examine the international law and policy framework for oil pollution preparedness and response and the extent to which it has been implemented in the South China Sea and broader East Asian seas. It will then analyse a recent global initiative that has been taken to improve the preparedness of the region to address a significant oil or gas spill in the South China Sea and broader East Asian seas.
\end{abstract}

\section{Keywords}

seas, east, sea, china, south, response, asian, preparedness, stemming, pollution, oil, cooperation, tide, black

Disciplines

Arts and Humanities | Law

\section{Publication Details}

R. M. Warner, 'Stemming the black tide: cooperation on oil pollution preparedness and response in the South China Sea and East Asian Seas' (2015) 18 (2) Journal of International Wildlife Law and Policy 184-197. 


\title{
Stemming the Black Tide: Cooperation on Oil Pollution Preparedness and Response in the South China Sea and East Asian Seas
}

\section{Robin Warner}

\section{Professor}

\author{
Australian National Centre for Ocean Resources and Security (ANCORS) \\ University of Wollongong, NSW Australia
}

\section{Introduction}

As global hydrocarbon resources on shore steadily decline, there has been an increase in offshore hydrocarbon exploration and exploitation. Some estimates suggest that there are over 6,000 off-shore oil and gas installations worldwide. ${ }^{1}$ Notwithstanding simmering disputes over the territorial sovereignty and associated maritime zones of a number of island groups in the South China Sea and adjacent East Asian seas, exploration for offshore oil and gas resources under national and joint development regimes has become a prominent feature of these areas. It is estimated that there are now over 1390 offshore oil and gas installations in the South China Sea and East Asian seas. ${ }^{2}$ This raises the question of how well prepared States bordering the South China Sea and the broader East Asian seas are to respond to a major oil spill from an offshore installation in the region. In recent years, two spectacular oil spills from off-shore installations have occurred, one off the North-West shelf of Western Australia from the Montara platform in 2009, the other in the Gulf of Mexico from the Deepwater Horizon rig in 2010. Leaking oil from those incidents over a number of months caused major damage to the coastlines of the States with

\footnotetext{
${ }^{1}$ Joint Group of Experts on the Scientific Aspects of Marine Environmental Protection (GESAMP), Estimates of Oil Entering the Marine Environment from Sea-based Activities, GESAMP Reports and Studies 75, 43, paragraph 195.

${ }^{2}$ Youna Lyons, "Transboundary Pollution from Offshore Oil and Gas Activities in the Seas of Southeast Asia" in Robin Warner and Simon Marsden (eds.), Transboundary Environmental Governance; Inland Coastal and Marine Perspectives (Ashgate Publishing Ltd, 2012) , 171.
} 
jurisdiction over the drilling as well as those of neighbouring States. The damage to the marine resources and biodiversity of the surrounding waters was extensive and industries dependent on the environmental integrity and health of these waters suffered commensurately. In addition, the costs of cleaning up such widespread and injurious oil spills were huge. ${ }^{3}$

Almost a third of global crude oil and half of global liquefied natural gas (LNG) passes through the South China Sea annually. ${ }^{4}$ China is also the world's largest oil importer. ${ }^{5}$ All these factors contribute to the high potential for an oil or gas spill disaster in the South China Sea and the broader East Asian seas. This article will examine the international law and policy framework for oil pollution preparedness and response and the extent to which it has been implemented in the South China Sea and broader East Asian seas. It will then analyse a recent global initiative that has been taken to improve the preparedness of the region to address a significant oil or gas spill in the South China Sea and broader East Asian seas.

\section{Environmental Impacts of Offshore Hydrocarbon Activities}

The commercial harvesting of offshore hydrocarbons began around the turn of the $19^{\text {th }}$ and $20^{\text {th }}$ centuries and in the 1930 s offshore oil production began in the Caribbean and the Gulf of Mexico. ${ }^{6}$ Currently over a hundred countries are producing offshore oil and gas or are in the exploration stages for these resources. The risks posed by offshore hydrocarbon activities to the surrounding marine environment and its biodiversity are high throughout the exploration and exploitation phases and beyond. Adverse impacts on the marine environment are caused by a variety of activities associated with oil and gas exploration

\footnotetext{
3 Jonathan L. Ramseur and Curry L.Haggerty, Deepwater Horizon Oil Spill Recent Activities and Ongoing Developments (Congressional Research Service, Washington DC, 12 May 2014) 2; Australian Maritime Safety Authority, Response to the Montara Wellhead Platform Incident, (Australian Government, Canberra, March 2010).

${ }^{4}$ Yoppy Tan, "The Growth in Energy Activities in the South China Sea. Are We Truly Prepared?" Proceedings of the International Oil Spill Conference (IOSC), 2014 ioscproceedings.org/doi/pdf/10.7901/2169-3358-1995-1$503,2$. US Energy Information Administration, Analysis Briefs, South China Sea, 7 February 2013, http://www.eia.gov/countries/regions-topics.cfm?fips=scs ${ }^{5}$ lbid.

${ }^{6}$ Chester Brown, "International Environmental Law in the Regulation of Offshore Installations and Seabed Activities: The Case for a South Pacific Regional Protocol" (1998) 17 Australian Mining and Petroleum Law Journal 110; Naama Hasson, "Deep Water Offshore Oil Exploration Regulation: the Need for a Global Regulation Regime" (2013) 4 Washington and Lee Journal of Energy, Climate and Environment 278.
} 
including seismic surveys, oil drilling, the use of oil based drilling muds and explosives, the accidental spillage and leakage of oil from offshore installations, the escape of oil from ruptured pipelines on the seabed and the disposal of sewage and garbage from offshore installations. ${ }^{7}$ An enduring impact on the marine environment is the disturbance of marine ecosystems by disused or abandoned platforms which are past their economic use. While intentional discharges from offshore installations are rare, since they are not in the commercial interests of operators, accidental discharges are much more common due to blowouts and spillage. The number of blowouts from offshore installations is five times higher than from on shore installations and offshore blowouts are more likely to result in fire. ${ }^{8}$ Operational pollution from offshore oil and gas installations is also a problem. This involves discharges of oily water produced during drilling, the dumping of oil related debris and oil based drilling muds from installations and the dissolving of chemical biocides used to discourage sedentary marine species from attaching themselves to platforms.

\section{International Law Framework for Oil Pollution Prevention, Preparedness and Response}

\section{UN Convention on the Law of the Sea (LOSC)}

The LOSC contains overarching provisions on protection and preservation of the marine environment and the prevention reduction and control of marine pollution from seabed activities. These provide a framework for cooperation towards these objectives but leave detailed implementation to States and regional organisations. The majority of coastal States bordering the South China Sea and East Asian seas are parties to the LOSC. ${ }^{9}$ States Parties have a general obligation to protect and preserve all parts of the marine environment under Article 192 of the LOSC and in accordance with Article 194(1), must take all measures consistent with the LOSC to prevent, reduce and control pollution of the marine environment from any source. They must also ensure that activities under their jurisdiction or control are conducted so as not to cause damage by pollution to other States and their environment, and that pollution arising from such activities does not spread beyond the areas where they exercise sovereign rights such as the exclusive economic zone (EEZ) and

\footnotetext{
${ }^{7}$ Ibid.

${ }^{8}$ Ibid.

${ }^{9}$ United Nations, Chronological List of Ratifications of, Accessions and Successions to the Conventions and related agreements http://www.un.org/Depts/los/reference_files/chronological_lists_of_ratifications.htm\#The United Nations Convention on the Law of the Sea
} 
the continental shelf. ${ }^{10}$ States must take measures to deal with all sources of pollution of the marine environment including from offshore installations. Of particular relevance to offshore installations is the stipulation that such measures should be designed to minimize to the fullest possible extent pollution from installations and devices used in exploration of the natural resources of the seabed and subsoil. ${ }^{11}$ Measures should encompass preventing accidents, dealing with emergencies, ensuring safety of operations at sea and regulating the design construction and equipment, operation and manning of offshore installations and devices. ${ }^{12}$ Laws, regulation and measures adopted by coastal States must be no less effective than international rules, standards and recommended practices and procedures and States must endeavour to harmonise their policies on these issues at the appropriate regional level. ${ }^{13}$ As well as a general duty to cooperate in formulating and elaborating international rules, standards and recommended practices and procedures for protecting and preserving the marine environment under Article 197 of the LOSC, States bordering semi-enclosed seas such as the South China Sea have specific obligations to cooperate with each other in protecting and preserving the marine environment and conserving and managing, exploring and exploiting the natural resources of the sea under Article 123 of the LOSC.

Other provisions of the LOSC establish a coastal State's jurisdiction over offshore installations within its territorial sea, EEZ and on the continental shelf and its regulatory powers in relation to such installations. The coastal State has sovereignty over its territorial sea including the seabed and subsoil under the water column out to a maximum breadth of 12 nautical miles from the territorial sea baselines. ${ }^{14}$ It may adopt laws and regulations in relation to all matters connected with offshore installations located within that zone. ${ }^{15}$ In the EEZ out to a maximum breadth of $200 \mathrm{~nm}$ from its territorial sea baselines the coastal State has sovereign rights over the exploration and exploitation of natural resources including offshore oil and gas and jurisdiction over the establishment and use of offshore installations. ${ }^{16}$ It has the exclusive right to construct such installations and jurisdiction with

\footnotetext{
${ }^{10}$ LOSC Article 194(2).

${ }^{11}$ LOSC Article 194(3)(c).

${ }^{12}$ Ibid.

${ }^{13}$ LOSC Article 208(3) and (4).

${ }^{14}$ LOSC Articles 2 and 3.

${ }^{15}$ LOSC Article 21(1)(b).

${ }^{16}$ LOSC Article 56(1)(a) and (1)(b).
} 
regard to customs, fiscal, health, safety and immigration laws and regulations relating to such installations. ${ }^{17}$ It must give due notice of the construction of such installations and is responsible for removing any abandoned or disused installations to ensure safety of navigation. ${ }^{18}$ Such removal must take into account fishing, the protection of the marine environment and safety of navigation. The coastal State may establish 500 metre safety zones around such installations from which foreign vessels are excluded primarily for the purpose of safety of navigation. ${ }^{19}$ The coastal State also exercises sovereign rights over the continental shelf for the purpose of exploring and exploiting its natural resources including oil and gas. ${ }^{20}$ Although there is no specific environmental jurisdiction provided over the continental shelf in the LOSC, the coastal State has the general obligations provided for in Part XII of the LOSC to protect and preserve the marine environment and to take all measures necessary to prevent reduce and control all sources of marine pollution of the continental shelf.

\section{Status of Offshore Installations under International Law}

Offshore installations are not easily defined under international law as most oil and gas installations have both mobile and fixed features. It is clear that offshore installations do not meet the definition of island under Article 121(1) of the LOSC as they are not naturally formed areas of land. Classifying offshore installations as ships which fall under the control of flag States rather than coastal States is also problematic. There is no uniform definition of a "ship" under international law. A range of international conventions have defined "ship" differently to include or exclude offshore installations. The term "ship" in the 1992 International Convention on Civil Liability for Oil Pollution Damage and the 1992 International Convention on the Establishment of an International Fund for Compensation for Oil Pollution Damage includes vessels that are for the time being used for the storage of oil, known as floating storage and offloading units (FSUs). ${ }^{21}$

In contrast, the International Convention Relating to Intervention on the High Seas in Cases of Oil Pollution Casualties defines "ship" in Article 2(2) as meaning:

\footnotetext{
${ }^{17}$ LOSC Article 60(1) and (2).

${ }^{18}$ LOSC Article 60(3).

${ }^{19}$ LOSC Article 60(4).

${ }^{20}$ LOSC Article 77(1).

${ }^{21}$ International Convention on Civil Liability for Oil Pollution Damage, Article 1(1); International Convention on the Establishment of an International Fund for Compensation for Oil Pollution Damage, Article 1(2).
} 
“(a) any seagoing vessel of any type whatsoever, and

(b) any floating craft, with the exception of an installation or device engaged in the exploration and exploitation of the resources of the seabed in the ocean floor and the subsoil thereof"

expressly excluding offshore installations from the ambit of the Convention.

In general, the practice has been to classify mobile offshore structures as subject to coastal State regulation when fixed to or submerged on the seabed under the jurisdiction of a particular coastal State, and for their status to revert to that of a ship when they are mobile.

Other conventions principally relevant to vessel source pollution have only limited application to offshore oil installations. The International Convention for the Prevention of Pollution from Ships (MAPOL 73/78) is relevant to global environmental regulation of offshore hydrocarbon activities due to its inclusion of floating craft and fixed or floating platforms in its definition of "ship." 22 Its application is limited, however, by Article 2(3(b) which states that the definition of discharge under the Convention:

"does not include (i) dumping within the meaning of the Convention on the Prevention of Marine Pollution by Dumping of wastes and other Matter; or

(ii)release of harmful substances directly arising from the exploration, exploitation and associated offshore processing of seabed mineral resources."

The application of MARPOL 73/78 and its six technical Annexes is therefore confined to nonoperational discharges not associated with the exploration, exploitation and associated offshore processing of offshore oil and gas. It would apply to an installation when it is mobile to and from its drilling location. The main operative provisions of the Convention on the Prevention of Marine Pollution by Dumping of Wastes and other Matter (London Convention) and its 1996 Protocol impose a duty on contracting parties to promote the effective control of pollution of the marine environment and to take steps to prevent the pollution of the sea by dumping of waste and other matter. The London Convention and

\footnotetext{
${ }^{22}$ International Convention for the Prevention of Pollution from Ships (MARPOL 73/78), Article 2(4).
} 
Protocol are limited in their application to offshore hydrocarbon activities for although "dumping" is defined as "any deliberate disposal at sea of waste or other matter from vessels, aircraft, platforms or other man-made structures at sea and (ii) any deliberate disposal at sea of vessels, aircraft, platforms or other man-made structures at sea", it excludes the disposal at sea of "wastes incidental to or derived from the normal operations of vessels, aircraft, platforms or other man-made structures at sea." ${ }^{23}$ Accordingly, dumping of wastes or other matter from offshore installations would only be within the ambit of the London Convention or Protocol if it occurred outside the normal drilling and processing operations of the offshore installation. Therefore the only dumping matters covered by the London Convention and Protocol in relation to offshore hydrocarbon installations are the dumping of unwanted materials produced in the course of operations on the platform and the dumping of disused offshore installations themselves.

\section{Global Standards for Offshore Hydrocarbon Activities}

Although there have been many calls for global regulation of offshore hydrocarbon activities, there is no comprehensive international agreement which prescribes international environmental standards or liability and compensation provisions for the operation of offshore hydrocarbon installations. In 1996, the Commission on Sustainable Development (CSD) concluded that there was no need for such global regulation but did support the negotiation of regional instruments to deal with pollution from offshore hydrocarbon activities. ${ }^{24}$ IMO has been similarly reluctant in recent resolutions to embark on the development of a global liability and compensation regime to deal with such pollution. ${ }^{25}$ While there has been no prescription of global environmental standards or liability and compensation provisions for the operation of offshore hydrocarbon installations, there is an IMO global regime for oil pollution preparedness and response, the International Convention for Oil Pollution Preparedness, Response and Cooperation (OPRC) which has been implemented in many regions.

\footnotetext{
${ }^{23}$ Convention on the Prevention of Marine Pollution by Dumping of Wastes and other Matter (London Convention), Article III(1).

${ }^{24}$ Brown, above note 6, 109.

${ }^{25}$ Rosalie Balkin, "Is there a place for the regulation of offshore oil platforms within international maritime law? If not, then where?" Paper delivered at Comite Maritime International Dublin Symposium, September 2013, www.cmi2013dublin.com/download/file/192 3.
} 


\section{International Convention for Oil Pollution Preparedness Response and Cooperation (OPRC)}

The International Convention on Oil Pollution Preparedness, Response and Co-operation (OPRC) was adopted on 30 November 1990 and entered into force on 13 May 1995.

Parties are required to establish measures for dealing with oil pollution incidents, either nationally or in co-operation with other countries. ${ }^{26}$ Ships are required to carry a shipboard oil pollution emergency plan and operators of offshore units including offshore installations under the jurisdiction of Parties are also required to have oil pollution emergency plans or similar arrangements which must be co-ordinated with national systems for responding promptly and effectively to oil pollution incidents. ${ }^{27}$ Ships are required to report incidents of pollution to coastal authorities and the Convention details the actions that are then to be taken. ${ }^{28}$ It also calls for the establishment of stockpiles of oil spill combating equipment, the holding of oil spill combating exercises and the development of detailed plans for dealing with pollution incidents. ${ }^{29}$ Parties to the convention are also required to provide assistance to others in the event of a pollution emergency and provision is made for the reimbursement of any assistance provided. ${ }^{30} \mathrm{~A}$ Protocol to the OPRC relating to hazardous and noxious substances (OPRC-HNS Protocol) was adopted in 2000.

\section{Regional Agreements on Oil Spill Response}

At the regional level, there are some key examples of coastal States bordering semienclosed seas developing regional protocols for oil spill preparedness and response. One of the earliest, even pre-dating OPRC, is the 1989 Protocol concerning Marine Pollution resulting from Exploration and Exploitation of the Continental Shelf to the Kuwait Regional Convention for the Protection of the Marine Environment from Pollution. This was the first United Nations Environment Programme (UNEP) convention dealing with pollution from offshore operations. Under this agreement offshore operations can only be licensed after

\footnotetext{
${ }^{26}$ International Convention on Oil Pollution Preparedness, Response and Co-operation (OPRC), Article 1(1).

${ }^{27}$ OPRC, Article 3(1)(a) and (2).

${ }^{28}$ OPRC, Articles 4 and 5.

${ }^{29}$ OPRC Article 6(1) and (2).

${ }^{30}$ OPRC, Article 7.
} 
the operator has completed an environmental impact assessment (EIA). ${ }^{31}$ Parties to the agreement must also take all practical measures to ensure that the everyday running of operations as well as safety procedures and overall maintenance are in accordance with good oilfield or other relevant industry practice. ${ }^{32}$ The regulation of oil discharges, and disposal of drilling muds, garbage and sewage from offshore installations is based on provisions contained in the relevant MARPOL 73/78 technical Annexes. ${ }^{33}$ A chemical use plan must also be filed before the operator may use any chemicals. ${ }^{34}$ The Protocol also includes provisions about the aftermath of any operations on the continental shelves of the Parties and combating of pollution emergencies but omits any provisions on liability and compensation. $^{35}$

Another example is the 1992 Convention on the Protection of the Marine Environment of the Baltic Sea Area which provides that Parties must take all appropriate measures to prevent pollution arising from operations on the seabed of the Convention Area. ${ }^{36}$ Annex VI of the Convention imposes an obligation on contracting parties to prevent and eliminate pollution from offshore activities by using the principles of best available technology and best environmental practices. This involves conducting prior EIAs, placing restrictions on the use of oil based drilling muds and limits on the oil content of discharged production water and displacement water in accordance with MARPOL 73/78 Annex I standards. Annex VI also obliges parties to file reports, have a contingency plan and ensure that disused offshore units are removed.

Finally the 1994 Protocol for the Protection of the Mediterranean Sea against Pollution resulting from Exploration and Exploitation of the Continental Shelf and the Seabed and its Subsoil requires Parties to take, individually or through bilateral or multilateral cooperation, all appropriate measures to prevent abate combat and control pollution from offshore activities in the Protocol Area by ensuring the best available environmentally effective and

\footnotetext{
${ }^{31}$ Protocol concerning Marine Pollution resulting from Exploration and Exploitation of the Continental Shelf to the Kuwait Regional Convention for the Protection of the Marine Environment from Pollution (Kuwait Protocol), Article IV.

${ }^{32}$ Kuwait Protocol, Article VII.

${ }^{33}$ Kuwait Protocol, Articles IX and X.

${ }^{34}$ Kuwait Protocol, Article XI.

${ }^{35}$ Kuwait Protocol, Article XIII.

${ }^{36}$ Convention on the Protection of the Marine Environment of the Baltic Sea Area (Helsinki Convention), Article 12.
} 
economically appropriate techniques are used for this purpose. ${ }^{37}$ All offshore hydrocarbon activities are subject to prior written authorisation which will be granted only if the operator complies with requirements including prior EIA and plans for the removal of the platform once operations cease. ${ }^{38}$ Common standards are imposed for discharges from platforms which cannot be less restrictive than a maximum oil content of $51 \mathrm{mg}$ per litre undiluted for machinery space drainage and a monthly average of $40 \mathrm{mg}$ per litre but not exceeding at any time $100 \mathrm{mg}$ per litre for production water. ${ }^{39}$ MARPOL 73/78 standards are adopted for the disposal of sewage and garbage. ${ }^{40}$

\section{Regional Arrangements for Oil Spill Preparedness and Response in the South China Sea and East Asian Seas}

Some countries bordering the South China Sea and East Asian Seas have developed bilateral and multilateral arrangements for oil spill preparedness and response but these arrangements do not currently provide comprehensive coverage for the region and in some cases, have not addressed the critical details of procedures and means to import equipment to the impacted country. The origin of this lack of cooperation and coordination has been identified by one commentator as relating to concerns surrounding national sovereignty and bureaucracy. ${ }^{41}$ In Tan's view, most countries in the region view national integrity as their priority and consequently enforce strict control over their borders. As a result it is sometimes difficult to overcome these obstacles even in the event of an emergency such as a massive oil spill. ${ }^{42}$

\section{ASEAN Oil Spill Response Plan (ASEAN OSRAP)}

The ASEAN Oil Spill Response Plan (ASEAN OSRAP) is a South East Asia wide arrangement. It is a memorandum of understanding $(\mathrm{MoU})$ on oil spill response cooperation which was signed by six countries (Brunei Darussalam, Indonesia, Malaysia, Philippines, Singapore and Thailand) in $1994 .{ }^{43}$ The objective of the MoU is to provide a cooperative plan for mutual assistance from member States

\footnotetext{
${ }^{37}$ Protocol for the Protection of the Mediterranean Sea against Pollution resulting from Exploration and Exploitation of the Continental Shelf and the Seabed and its Subsoil (Barcelona Protocol), Article 3(1).

${ }^{38}$ Barcelona Protocol, Articles 4 and 5.

${ }^{39}$ Barcelona Protocol, Article 10.

${ }^{40}$ Barcelona Protocol, Articles 11 and 12.

${ }^{41}$ Tan, above note 4,2 .

${ }^{42}$ Ibid.

${ }^{43}$ Ibid, 12.
} 
and organisations in the event of major oil spill incidents which exceed the response capability of the national government. The ASEAN Council on Petroleum (ASCOPE), made up of national petroleum corporations of ASEAN countries, is considering forming an ASCOPE oil spill contingency plan to provide equipment and manpower to member countries. ${ }^{44}$ The proposed plan will complement the ASEAN OSRAP.

\section{National Responses to Oil Spill Preparedness and Response}

In general, oil spill response arrangements and resources in the South China Sea and broader East Asia seas are led by the national authorities. ${ }^{45} \mathrm{~A}$ State that has ratified the OPRC must follow a set of compulsory measures which represent the minimum legal requirements to improve preparedness and compensation. This is still not well implemented in the South China Sea as only four out of ten countries, China, Malaysia, Singapore and Thailand, have ratified the OPRC. ${ }^{46}$ Most of the countries in the region have an approved list of dispersants but the methodology for applying the dispersant during response often requires a separate set of approval protocols. Pre-agreement on dispersant use in defined zones for defined oils needs to be systematically developed and integrated into national oil spill contingency plans. ${ }^{47}$

\section{Collaborative Initiatives to Protect the Marine Environment of East Asian Seas}

Over the last two decades, there have been some practical examples of regional non treaty based initiatives that have been taken in the East Asian Seas to protect the shared marine environment and contribute to preventing reducing and controlling marine pollution including oil pollution in the region. Some of these have included oil spill preparedness and response projects.

\section{Partnerships in Environmental Management in East Asian Seas (PEMSEA)}

PEMSEA reflects a common concern among East Asian States for their shared marine environment in the semi-enclosed seas of East Asia. A group of 11 States and 20 non-State entities are partners in PEMSEA which was established as a regional project of the Global Environment Facility (GEF) in 1994 with the initial aim of preventing and managing marine

\footnotetext{
${ }^{44}$ Ibid.

${ }^{45}$ Ibid, 9.

${ }^{46}$ Ibid, 6.

${ }^{47}$ Ibid, 8 .
} 
pollution in the East Asian seas. ${ }^{48}$ The geographic area of responsibility covered by PEMSEA is subject to substantial and rising pressures in terms of sources of marine pollution. Approximately $50 \%$ of the world's oil supply and $30 \%$ of the world's commerce pass through the Straits of Malacca and Singapore which are both located within PEMSEA's area of coverage. In 2013 there were 77,973 transits of the Straits of Malacca by vessels of 300 gross tonnes or more, passing the previous high of 76,381 transits in $2008 .^{49}$ More than 41,000 ships pass through the South China Sea annually. ${ }^{50}$

Since 2003, PEMSEA's mission has progressed to the more comprehensive objective of building interagency, inter-sectoral and intergovernmental partnerships for achieving the sustainable development of East Asian seas. It has been engaged in forming the necessary partnerships, capacity and operating mechanisms to implement relevant aspects of the 2002 World Summit on Sustainable Development (WSSD) joint plan of implementation (JPOI) and the Millenium Development Goals for protecting life support systems and enabling the use of coastal and marine resources of the region. In this endeavour, it has established a track record of forging links between multiple actors in East Asia and beyond with common goals for the conservation of marine biodiversity and sustainable use of marine resources. ${ }^{51}$ In 2003, participating countries in PEMSEA adopted the Sustainable Development Strategy for the Seas of East Asia (SDS-SEA) as a management framework for integrated implementation of various International Maritime Organisation (IMO) marine pollution conventions and other multilateral instruments addressing the coastal and marine environments. SDS-SEA has more than 50 action programmes many of which focus on prevention, reduction and control of marine pollution. ${ }^{52}$

Programmes and plans related to oil spill prevention, preparedness and response initiated under SDS-SEA include the Framework Programme for Joint Oil Spill Preparedness and Response in the Gulf of Thailand (Framework Programme) and the Manila Bay Oil Spill Contingency Plan (Manila Bay Plan). The Framework Programme involves three PEMSEA

\footnotetext{
${ }^{48}$ Partnerships in Environmental Management in East Asian Seas (PEMSEA),http://www.pemsea.org/

${ }^{49}$ Sea Trade Global, "Malacca Strait traffic hits an all-time high in 2014, VLCCs and dry bulk lead growth" http://www.seatrade-global.com/news/asia/malacca-strait-traffic-hits-an-all-time-high-in-2014-vlccs-and-drybulk-lead-growth.html

50 Ibid.

${ }^{51}$ PEMSEA, above note 48.

${ }^{52}$ PEMSEA, Sustainable Development Strategy, http://www.pemsea.org/sustainable-development-strategy
} 
State partners, Cambodia, Thailand and Vietnam. On 12 January 2006, Ministers from the three countries issued a joint statement on partnership in Oil Spill Preparedness and Response Cooperation in the Gulf of Thailand which contains a tripartite intergovernmental agreement committing participating countries to mutual support and assistance in combating oil spills in the Gulf of Thailand region and endorses a Framework Programme for achieving this. ${ }^{53}$ The Framework Programme integrates the implementation of the OPRC, the 1971 Fund Convention and the 1969 Civil Liability Convention in relation to damage compensation and is a working model for integrated implementation of these international instruments at the sub-regional level. PEMSEA has also provided technical advice on the development of some oil spill contingency plans in the East Asia region. With technical input from PEMSEA, the Manila Bay Plan was completed as a joint effort of the Philippines Coastl Guard, the petroleum industry, the shipping industry and the local governments in Manila Bay. ${ }^{54}$

\section{Global Initiative SEA- Intervention in South East Asia to Improve Oil Spill Preparedness and Response}

The Global Initiative (GI) is a programme under which Government bodies, the shipping and oil industries and other partners are working together to encourage and facilitate the development and implementation of national and regional oil spill contingency plans and to increase the ratification of oil spill related international conventions. ${ }^{55}$ It also connects the International Oil Pollution Compensation (IOPC) funds, the Tanker Owners Pollution Federation (ITOPF), Governments, local industries, donor agencies and nongovernmental organisations so that they can exchange facts, explain their responsibilities, contributions, expectations and ideas to advance national preparedness. ${ }^{56}$ Within the GI, IMO provide the intergovernmental liaison point and the International Petroleum Industry Environmental Conservation Agency (IPIECA) facilitates industry involvement. The governments, local industries, donor agencies and NGOs provide the regional and local input, which allows the development of a focused work programme for implementation. ${ }^{57}$ The GI for South East

\footnotetext{
${ }^{53}$ PEMSEA, PEMSEA News, http://www.pemsea.org/news/fourth-gulf-thailand-national-contact-pointsmeeting-chonburi-thailand

${ }^{54}$ PEMSEA, Manila Bay Oil Spill Contingency Plan, http://www.pemsea.org/node/86

${ }_{55}^{55}$ IMO/IPIECA Global Initiative, http://www.ipieca.org/publication/imo-ipieca-global-initiative-0

${ }^{56}$ Ibid.

${ }^{57}$ Ibid.
} 
Asia was launched in Jakarta, Indonesia on 19 March 2013 and has been working through a series of engagement programmes towards specified targets for two years. ${ }^{58}$ It is funded by IMO and by members of the IPIECA including Chevron, ExxonMobil, Pertamina and Shell.

A range of questions are being addressed by the GI SEA including:

- How to ensure that there is integration of oil spill responses between the South China Seas countries

- What industry knowledge there is on the equipment stockpile available to respond to oil spill contingencies

- What obstacles there are to an efficient response to major oil spills

- How the industry should organise to ensure optimum response capabilities

- Whether government control and direction of response to a major incident expected and if so, whether existing national response systems are optimally designed to accommodate that control ${ }^{59}$

Since its inception in March 2013 the GI SEA has engaged in a number of projects to revitalise and strengthen existing bilateral, multilateral and national arrangements for oil spill preparedness and response in South East Asia. During 2014 it held an ASEAN Regional Workshop on Oil Spill Preparedness and Response in which a gap and needs assessment of the state of preparedness and response in the ASEAN member countries was conducted. A Gulf of Thailand Workshop on Subregional Cooperation was also held in 2014 with the aim of strengthening cooperation on oil spill preparedness and response between the three Gulf of Thailand countries, Cambodia, Thailand and Vietnam. Two workshops were held in Indonesia and the Philippines in 2014 to update and revise their National Plans for Oil Spill Preparedness and Response. ${ }^{60}$ In the case of Indonesia, the objective was to assist the Indonesian Government to make progress on their Tier 3 Oil Spill Contingency Plan and to engage the participation of the local oil and gas industry players. Similar to Indonesia, the Philippines workshop was designed to assist the Philippines Government in the revision and

\footnotetext{
${ }^{58}$ IMO, “IMO and IPIECA Launch Global Initiative for South East Asia (GI-SEA) to improve oil spill preparedness and response capabilities", http://www.imo.org/MediaCentre/PressBriefings/Pages/08-GlSEA.aspx\#.VSOECqN--po

${ }^{59}$ GI SEA, About GI SEA, http://www.gisea.org/?page_id=5

${ }^{60}$ GI SEA, Activities, http://www.gisea.org/?page_id=7
} 
updating of their 2008 National Plan for Oil Spill Preparedness and Response and engage the participation of the local oil and gas industry.

\section{Conclusion}

The growing demand for energy in the East Asian region is unlikely to decrease and is likely to trend upwards. In view of the large number of offshore oil installations and international shipping movements in the South China Sea and broader East Asian seas, national regional and global initiatives to respond to oil spills from both these sources are all beneficial for the conservation of marine biodiversity within and beyond the region. Given the deficiencies in environmental safeguards, oil pollution contingency plans and transboundary compensation arrangements for offshore installations exposed by recent disasters such as the Deepwater Horizon and Montara oil spills, there is an urgent need to set global standards for environmentally responsible offshore hydrocarbon activities. When considered as a whole, the existing international law framework is limited in its ability to prevent pollution from offshore hydrocarbon activities for a variety of reasons including the generality of the duties imposed on States, the lack of quantitative standards, the reliance in global conventions such as the LOSC and OPRC on the later development of specific regional and national regulations and in some cases the lack of ratifications of global conventions. In the absence of global standards and best practice guidance, arrangements for oil spill preparedness and response should be at the forefront of regional priorities particularly for States bordering semi-enclosed seas such as the South China Sea. While some regions have long standing oil pollution preparedness and response agreements, such arrangements have been slow to develop in South East Asia and do not cover all areas of the South China Sea and broader East Asian seas. The recent GI SEA intervention in the region has highlighted the requirement for a more integrated and coordinated system of responding to oil spills. The high potential for such spills to cause major damage to marine biodiversity across national boundaries underscores the benefits to be gained from strong regional protocols on oil spill preparedness and response. These should be continually refined and exercised among all the countries bordering the South China Sea and broader East Asian Seas. 